Junius Bird, assistant in the Museum's Department of Anthropology. Mr. Bird will conduct excavations in the recent deposits overlying the fossil beds, in which have been found evidence of early human occupation, such as chalcedony tools, including scrapers and knives, and sherds of a black pottery.

An expedition under Dr. Grace Ramsay Fisher, of the Department of Education of the Museum, has been engaged in recording the life and work of Indian artist craftsmen in Mexico, a field in which surviving primitive conditions still afford a profitable field of research and recordings. Collections will illustrate typical examples of representative native craftsmanship in weaving wool, cotton, and plant fibres, embroidery and beading, pottery, showing the regional designs, leather, metal and lacquer work, masks, musical instruments and toys. The areas covered were central, south-east and south-west Mexico, and coloured motion pictures illustrate the life of their villages. This material ultimately will be circulated by the Department of Education for use in schools and other educational institutions.

\section{Leprosy in Brittany}

IN his inaugural thesis (Thèse de Paris, 1940, No. 229), Dr. Y. M. Marlic states that leprosy disappeared from Brittany at the end of the seventeenth century, and no further mention was made of its occurrence there until 1892, when Zambaco Pacha, during a visit to the provinee, rediscovered the disease. Since then it has been the custom to describe Brittany as a leper country like the Mediterranean coast. Zambaco Pacha, however, found only two cases of leprosy in Brittany which were not indigenous, and since then only five cases in all have been described in Brittany in the course of forty-s zven years, namely, one by Jeanselme (probably indigenous), one by Loussot-Netter (indigenous), three by Gouin, two of which showed $B$. leproe, and two doubtful cases by Laferre, which were probably examples of leprosy without bacilli. Marhic therefore comes to the conclusion that leprosy does not appear to be more frequent in Brittany than in the other French provinces.

\section{Jute-Growing in the U.S.S.R.}

THe All-Union Institute of Plant Cultivation of the U.S.S.R. has for the past thirteen years been carrying on experiments in the cultivation of jute, and has proved that this important industrial crop can be grown successfully in the Soviet Union. From among 150 varieties imported from India and various other tropical and sub-tropical countries and planted by the Institute in certain districts of Transcaucasia and Central Asia, the species Corchorus capsularis and Corchorus olitorius have been selected. These plants yield 13-25 per cent fibre, and produce a crop of seeds, which will make it possible to cultivate jute in the U.S.S.R. on an industrial scale. At present the Institute is endeavouring to acclimatize species and varieties with a greater yield.

\section{Announcements}

Srr Arthur Hrul, director of the Royal Botanic Gardens, Kew, has been awarded the George Robert White Medal of the Massachusetts Horticultural Society.

Str Arthur MacNacty, chief medical officer of the Ministry of Health and of the Board of Education, is retiring on reaching the age limit. The Minister of Health and the President of the Board of Education have respectively appointed Sir Wilson Jameson to be chief medical officer of the Ministry and the Board. Sir Wilson Jameson is relinquishing the post of medical adviser to the Secretary of State for the Colonies, from which in the circumstances the Secretary of State did not feel that he could refuse to release him. He is also relinquishing the post of dean of the London School of Hygiene and Tropical Medicine and professor of public health in the University of London.

The Ministry of Food announces that the Flour (Vitaminization) Advisory Committee, which has recently been appointed, will have the assistance in its official capacities of Prof. D. M. S. Watson, F.R.S., of the Scientific Sub-Committee of the Food Policy Committee of the Cabinet, of Mr. P. N. R. Butcher, of the Ministry of Health, and of the following officers of the Ministry of Food : Sir Norman Vernon (director of flour milling), Prof. J. C. Drummond (scientific adviser), Dr. T. Moran (deputy scientific adviser), and Mr. J. H. Pillman (manager for imported flour).

ThE following appointments have recently been made in the Colonial Service: P. R. Akehurst, agricultural officer, Nyasaland; L. H. Browne, agricultural officer, Nigeria ; J. W. D. Goodban, agricultural officer, Nigeria ; A. P. MacWilliam, agricultural officer, Trinidad; D. B. Murray, agricultural officer, Nigeria ; P. Paine, agricultural officer, Nigeria; M. F. H. Selby, botanist, Nigeria; N. Harris, geologist, Uganda.

Dr. R. Lessing, of 50 Queen Anne's Gate, London, S.W.1, has a complete set of unbound copies of NATURE dating from 1918 up to the current issue. He is prepared to present these to any person, school or institute. Application should be made to Dr. Lessing direct.

THE Huxley Memorial Lecture of the Royal Anthropological Institute will be delivered by $\mathrm{Mr}$. H. J. E. Peake at 2.30 p.m. on November 26 , at the rooms of the Institute, 21 Bedford Square, London, W.C.1. The subject of the lecture will be "The Study of Prehistoric Times".

THE second of the Cantor lectures of the Royal Society of Arts will be delivered by Prof. S. J. Davies at 1.45 p.m. on November 25 , at the Society's rooms, John Adam Street, Adelphi, London, W.C.2. The subject of the lecture will be "Recent Developments in Internal Combustion Engines". 